\title{
Myocardial Iron overload quantification in a developing country: Tunisian first experience with financial challenges
}

\author{
Ismahen Ben Yaacoub-Kzadri', Chawkat Ramadane, Aicha Ben Miled, Najla Mnif \\ From 18th Annual SCMR Scientific Sessions \\ Nice, France. 4-7 February 2015
}

\section{Background}

Iron chelation treatment has increased life expectancy of patients with beta thalassemia major. Accurate assessement of heart iron overload is essential for managing chelation therapy. Nowadays, MRI-based iron overload quantification became the gold standard technique. However it remains too expensive in countries that cannot afford such technology, which ironically are endemic countries of thalassemia. The aim of our study is to evaluate the impact of measuring heart iron concentration by the means of MRI using a "low cost" technique in a developing country like ours with few financial resourses.

\section{Methods}

We studied prospectively 101 patients with beta thalassemia major. Serum ferritin and left ventricular ejection fraction were compared to cardiac T2* and myocardial iron concentration (MIC) assessed with a validated technique based on MRI relaxometry by the means of single echo $\mathrm{T} 2$ * sequences with crescent TE; and a free Excel speadsheet for post processing. Liver iron overload quantification was performed during the same examination and using the same method. The total duration of the examination was 20 to $25 \mathrm{~min}$ and post processing 5 to $10 \mathrm{~min}$.

\section{Results}

A significative negative correlation was found between serum ferritin levels and cardiac T2* and MIC values. Heart and liver $\mathrm{T}^{*}$ values showed a significative positive correlation. All patients with an altered LVEF had a heart $\mathrm{T} 2 * 10 \mathrm{~ms}$. Patients with moderate and severe myocardial iron overload benefited from optimization of

Radiology, Charles Nicolle Hospital, Tunis, Tunisia their chelation therapy. Close monitoring of severely overloaded patients was recommended.

\section{Conclusions}

Our results suggests that the single echo $\mathrm{T} 2 *$ technique coupled with Excel post processing is a fast, non-invasive, reliable and low cost method for the assessment of heart iron concentrationn, appropriate to the budget of the developing countries.

\section{Funding}

N/A.

Published: 3 February 2015

\section{doi:10.1186/1532-429X-17-S1-W21}

Cite this article as: Yaacoub-Kzadri et al:: Myocardial Iron overload quantification in a developing country: Tunisian first experience with financial challenges. Journal of Cardiovascular Magnetic Resonance 2015 17(Suppl 1):W21.

Submit your next manuscript to BioMed Central and take full advantage of:

- Convenient online submission

- Thorough peer review

- No space constraints or color figure charges

- Immediate publication on acceptance

- Inclusion in PubMed, CAS, Scopus and Google Scholar

- Research which is freely available for redistribution 